\title{
New variants in the glycogen synthase gene (GIn71His, Met416Val) in patients with NIDDM from eastern Finland
}

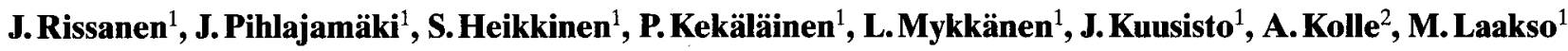 \\ ${ }^{1}$ Department of Medicine, University of Kuopio, Kuopio, Finland \\ 2 Taipalsaari Health Center, Taipalsaari, Finland
}

Summary Impaired glycogen synthesis after insulin stimulation accounts for most of the insulin resistance in patients with non-insulin-dependent diabetes mellitus (NIDDM). The glycogen synthase gene (GYS1), which encodes the rate-limiting enzyme for glycogen synthesis, is a promising candidate gene for NIDDM. Therefore, we screened all 16 exons of this gene by single-strand conformation polymorphism analysis in 40 patients with NIDDM (age $67 \pm 2$ years, body mass index $28.2 \pm 0.6 \mathrm{~kg} / \mathrm{m}^{2}$ ) from Taipalsaari, eastern Finland. The Gly464Ser variant (exon 11) and a silent polymorphism TTC342TTT (exon 7) have been reported previously. In addition, we found a new variant $\mathrm{Gln} 71 \mathrm{His}$ (exon 2) and a new amino acid polymorphism Met416Val (exon 10). An additional sample of 65 patients with NIDDM and 82 normoglycaemic men (age $54 \pm 1$ years, body mass index $26.3 \pm 1.4 \mathrm{~kg} / \mathrm{m}^{2}$ ) were screened. The allele frequency of the TTC342TTT silent substitution was 0.29 in both NIDDM and normoglycaemic subjects. The Gln71His and Gly464Ser variants were found in 1 $(1 \%)$ and $3(3 \%)$ subjects, respectively, of the 105 NIDDM patients and in none of the 82 normoglycaemic men. The Met416Val polymorphism was found in $16(15 \%)$ of the 105 NIDDM patients and in 14 $(17 \%$ ) of the 82 control subjects (all heterozygous). The Met416Val polymorphism was not associated with insulin resistance in two groups of normoglycaemic subjects. In conclusion, the new Glnz1His and Met416Val substitutions and other variants of the glycogen synthase gene are unlikely to make a major contribution to insulin resistance and NIDDM in diabetic patients from eastern Finland. [Diabetologia (1997) 40: 1313-1319]

Keywords Insulin resistance, glycogen synthesis, noninsulin-dependent diabetes mellitus, heredity, candidate gene.
Glycogen synthase (GS) [1,2] is the key enzyme catalysing glucose storage, which is the major pathway of glucose disposal in skeletal muscle [3]. Impaired formation of glycogen is a characteristic feature in noninsulin-dependent diabetes mellitus (NIDDM) [3-7]. This defect is often found together with decreased

Received: 17 April 1997 and in revised form: 30 June 1997

Corresponding author: M. Laakso, M.D., Professor and Chair, Department of Medicine, SF-70210 Kuopio, Finland Abbreviations: Gln71His, Glutamine71Histidine; Gly464Ser, Glycine464Serine; GS, glycogen synthase; GYS1, glycogen synthase locus; Met416Val, Methionine416Valine; PCR, polymerase chain reaction; SSCP, single-strand conformation polymorphism analysis. basal, insulin-stimulated [7-9] or total activity [4, 5] of GS or reduced activation of the GS enzyme by insulin $[4,7,9,10]$ in patients with NIDDM. The positive correlation between the activity of GS and glycogen content $[4,6]$ and non-oxidative glucose metabolism $[6,7,10-14]$ supports the view that the activity of GS is closely related to the amount of glycogen formed.

Several findings suggest that impaired GS activity may be an inherited defect in patients with NIDDM. First, insulin-stimulated activation of GS is reduced not only in patients with NIDDM, but also in their first-degree normoglycaemic relatives $[7,14]$. These findings imply that impaired GS activity may be an early and primary, and probably a genetically determined defect in the development of the disease. In 
agreement with these results, previous reports have indicated an association between the markers of the glycogen synthase gene (GYS1) and NIDDM in four populations. The XbaI-polymorphism of intron 14 of the GYS1 gene showed a significant association with NIDDM in Finnish [15] and French [16] populations, and microsatellite polymorphisms of the GYS1 gene were associated with NIDDM in the Japanese population [17] and in Pima Indians [18]. Furthermore, in vitro cultured fibroblasts [19] and skeletal muscle cells [20] from patients with NIDDM manifest decreased rates of glycogen synthesis [19] and reduced basal and insulin-stimulated GS activity [20]. This may indicate a defect in the GS protein per se, in the GS protein expression, in allosteric or covalent regulation of GS activity or in insulin-signal transduction pathway which leads to the activation of GS.

On the basis of biochemical, metabolic and genetic evidence, the GYS1 gene is a reasonably good candidate gene for insulin resistance. Previous studies on screening of the coding region of the GYS1 gene have, however, not revealed any variants that could explain reduced GS activity and insulin resistance $[18,21-23]$. In this article we report new variants in the coding region of the GYS1 gene in patients with NIDDM from eastern Finland.

\section{Subjects and methods}

Subjects and study protocol. All subjects who participated in this study were Finnish. The Finnish population is genetically quite homogenous, descending mainly from a small number of founders of Baltic and German origin [24]. Informed consent was obtained from all subjects after the purpose and potential risks of the study were explained to them. The protocol was approved by the ethics committee of the University of Kuopio and was in accordance with the Helsinki Declaration.

The 40 NIDDM subjects ( 20 men and 20 women) for the initial screening of the GYS1 gene were selected randomly from NIDDM patients visiting the Taipalsaari Health Center in eastern Finland. This small community was selected for this study because NIDDM exhibits a strong familial clustering in this community and because it has been in genetic isolation for centuries. The mean age of the NIDDM patients was $67 \pm 2$ years, body mass index $28.2 \pm 0.6 \mathrm{~kg} / \mathrm{m}^{2}$, fasting blood glucose $8.3 \pm 0.5 \mathrm{mmol} / \mathrm{l}$, duration of diabetes $8 \pm 1$ years, and age at onset of diabetes $59 \pm 2$ years.

The variants observed in the initial screening were analysed in additional samples of 65 patients with NIDDM, and also in 82 men who had normal glucose tolerance after a 75-g glucose load in an oral glucose tolerance test (Group 1). Table 1 gives the clinical characteristics of these study subjects. These additional 65 NIDDM patients included 53 subjects from a previous epidemiological study [25] and 12 NIDDM patients from Taipalsaari. The 82 unrelated normoglycaemic men had participated in our previous population-based study [26]. None of them had any chronic disease, any drug treatment that could influence carbohydrate metabolism, any abnormality in an oral glucose tolerance test (impaired glucose tolerance or diabetes according to the criteria of the World Health Organization [27]), or hypertension (use of antihypertensive drugs or
Table 1. Clinical characteristics of the study groups

\begin{tabular}{lcc}
\hline & $\begin{array}{l}\text { Normoglycaemic } \\
\text { group 1 } \\
(n=82)\end{array}$ & $\begin{array}{c}\text { NIDDM } \\
\text { subjects } \\
(n=105)\end{array}$ \\
\hline Gender (male/female) & $82 / 0$ & $54 / 51$ \\
Age (years) & $54 \pm 1$ & $66 \pm 1$ \\
Body mass index $\left(\mathrm{kg} / \mathrm{m}^{2}\right)$ & $26.3 \pm 1.4$ & $28.2 \pm 0.5$ \\
Fasting glucose $(\mathrm{mmol} / \mathrm{l})$ & $5.6 \pm 0.1$ & $8.8 \pm 0.3$ \\
Fasting insulin (pmol/l) & $55.9 \pm 4.0$ & $104.2 \pm 8.4$ \\
Age at onset of diabetes (years) & - & $54 \pm 1$ \\
Duration of diabetes (years) & - & $11 \pm 1$ \\
\hline
\end{tabular}

Data are means \pm SEM

systolic/diastolic blood pressure $>160 / 95 \mathrm{mmHg}$ ). None of the control subjects had a family history of diabetes. Because the allele frequency for an autosomal polymorphism should be independent of gender, these healthy men from a random population sample could be used in estimating the allele frequencies of the variants in the GYS1 gene in the Finnish population. The NIDDM patients were unrelated and they fulfilled the World Health Organization criteria for diabetes and NIDDM [27]. Each diabetic and control subject had normal liver, kidney, and thyroid function and no history of excessive alcohol intake.

The influence of the novel Met416Val polymorphism of the GYS1 gene on insulin sensitivity was investigated in group 1. Furthermore, an additional group of 295 normoglycaemic subjects ( 150 men and 145 women) were included as a separate group (Group 2) in order to investigate the effect of this new polymorphism on insulin sensitivity assessed by Bergman's Minimal Model in a large number of non-diabetic subjects. These subjects were a random sample of non-diabetic individuals (age $44 \pm 1$ years, body mass index $25.6 \pm 0.2 \mathrm{~kg} / \mathrm{m}^{2}$, fasting glucose $5.2 \pm 0.0 \mathrm{mmol} / 1$ and fasting insulin $56.2 \pm 1.7 \mathrm{pmol} / 1$ ) who had participated in our previous population-based studies in which we investigated the prevalence of atherosclerotic vascular disease and its risk factors [28]. These subjects did not have diabetes or impaired glucose tolerance according to the World Health Organization criteria [27] in an oral glucose tolerance test ( $75 \mathrm{~g}$ of glucose), current treatment with drugs that could influence carbohydrate metabolism, renal failure, or a serious illness.

In the initial screening the Gly464Ser variant of the GYS1 gene was found in three NIDDM patients from Taipalsaari. Because this sequence variant has been linked with insulin resistance [22] and because patients with familial combined hyperlipidaemia are insulin resistant, we screened 26 probands with familial combined hyperlipidaemia for this variant. To investigate the effect of the Gly464Ser variant on insulin sensitivity in these families, the spouses and first-degree relatives of these probands were screened for this variant. Insulin sensitivity among these subjects was evaluated by the euglycaemic clamp.

\section{Metabolic studies}

Euglycaemic hyperinsulinaemic clamp. The euglycaemic clamp technique [29] was performed after a 12-h fast as described previously [30] in subjects belonging to Group 1 and in relatives of patients with familial combined hyperlipidaemia. After blood was drawn at baseline, a priming dose of insulin (Actrapid $100 \mathrm{IU} / \mathrm{ml}$; Novo Nordisk, Gentofte, Denmark) was administered during the initial $10 \mathrm{~min}$ to raise insulin concentrations 
quickly to the desired level, where it was maintained by a continuous insulin infusion of $480 \mathrm{pmol}(80 \mathrm{mU}) / \mathrm{m}^{2}$ per min. Under these study conditions hepatic glucose is completely suppressed in normoglycaemic subjects [31]. Blood glucose was clamped at $5.0 \mathrm{mmol} / \mathrm{l}$ for the next $180 \mathrm{~min}$ by infusion of $20 \%$ glucose at varying rates according to blood glucose measurements performed at $5-\mathrm{min}$ intervals. The mean value for the last hour was used to calculate the rates of whole body glucose uptake.

Intravenous glucose tolerance test. The degree of insulin resistance was assessed in 295 normoglycaemic subjects (Group 2) by an intravenous glucose tolerance test after a 12-h fast. Two successive samples of blood glucose ( 5 min apart) were taken for measurement of fasting glucose and insulin levels. An intravenous glucose bolus $(0.3 \mathrm{~g}$ glucose $/ \mathrm{kg}$ body weight as a $50 \%$ solution administered over $90 \mathrm{~s}$ ) was then injected via the cannula into the non-sampled arm. Additional samples for the measurement of blood glucose and plasma insulin levels were taken at $4,6,8,10,19,22,29,37,67,90$, and $180 \mathrm{~min}$ [32]. At $20 \mathrm{~min}$, an intravenous injection of regular insulin $(0.03 \mathrm{U} / \mathrm{kg}$ body weight) was administered to increase the accuracy of the modelling analyses. Glucose utilization was analysed using the minimal model of glucose disappearance according to Bergman et al. [33]. The equations of this model provide measurements of the sensitivity of glucose elimination to insulin $\left(S_{i}\right.$, inversely proportional to insulin resistance) and glucose-dependent glucose elimination $\left(\mathrm{S}_{\mathrm{G}}\right)$.

Analytical methods. Plasma glucose levels during fasting and after an oral glucose load and blood glucose levels during the euglycaemic clamp were measured by the glucose oxidase method (2300 Stat Plus; Yellow Springs Instrument Co. Inc., Ohio, USA). For the determination of plasma insulin, blood was collected in tubes containing EDTA, and after centrifugation the plasma was stored at $-20^{\circ} \mathrm{C}$ until analysed. Concentration of plasma insulin was determined by a commercial double-antibody solid-phase radioimmunoassay (Phadeseph Insulin RIA 100; Pharmacia Diagnostics AB, Uppsala, Sweden). The interassay coefficient of variation for insulin was less than $8.7 \%$.

Single-strand conformation polymorphism analysis. DNA was prepared from peripheral blood leukocytes by a proteinase Kphenol-choloroform extraction method. All 16 exons and the intron-exon junctions of the GYS1 gene were amplified in a volume of $10 \mu \mathrm{l}$ with the polymerase chain reaction (PCR) using primers as reported previously [22]. Each reaction contained $100 \mathrm{ng}$ of genomic DNA, 5 pmol of each primer, $10 \mathrm{mmol} / \mathrm{l}$ Tris-HCL (pH 8.8), $50 \mathrm{mmol} / \mathrm{K} \mathrm{KCL}, 1.5-2.0 \mathrm{mmol} / \mathrm{l}$ $\mathrm{MgCl}_{2}, 0.1 \%$ Triton X-100, $200 \mu \mathrm{mol} / 1 \mathrm{dNTP}, 0.25$ units of DNA polymerase (Dynazyme DNA polymerase, Finnzymes, Finland) and $1.0 \mu \mathrm{Ci}$ of alpha ${ }^{32} \mathbf{P} \mathrm{dCTP}$. The PCR conditions were denaturation at $94^{\circ} \mathrm{C}$ for $3 \mathrm{~min}$, followed by $30-35$ cycles of denaturation at $94^{\circ} \mathrm{C}$ for $30 \mathrm{~s}$, annealing at $58-67^{\circ} \mathrm{C}$ for 30 $45 \mathrm{~s}$ and extension at $72^{\circ} \mathrm{C}$ for $30-60 \mathrm{~s}$ with final extension at $72^{\circ} \mathrm{C}$ for $4 \mathrm{~min}$. Single strand conformation polymorphism (SSCP) analysis was performed essentially according to the method of Orita et al. [34]. To obtain DNA fragments smaller than $220 \mathrm{bp}$, the PCR products of exons 1 and 5 were digested with HhaI, exon 2 with RsaI, exon 3 with Eco47III and exon 4 with NciI restriction enzyme. For SSCP analysis PCR products were first diluted 10-20 fold with $0.1 \%$ SDS, $10 \mathrm{mmol} / 1 \mathrm{EDTA}$ and then diluted (1:1) with loading mix ( $95 \%$ formamide, $20 \mathrm{mmol} / 1$ EDTA, $0.05 \%$ bromphenol blue, $0.05 \%$ xylene cyanol). After denaturation at $98^{\circ} \mathrm{C}$ for $3 \mathrm{~min}$, samples were immediately cooled on ice and $2 \mu$ l of each sample was loaded onto a $6 \%$ non-denaturating polyacrylamide gel (acrylamide/
$\mathrm{N}, \mathrm{N}$-methylene-bis-acrylamide ratio $49: 1$ ) containing $10 \%$ glycerol. Each sample was run at two different gel temperatures: 1) $38^{\circ}-40^{\circ} \mathrm{C}$ for approximately $4 \mathrm{~h}$, and 2) $29^{\circ} \mathrm{C}$ for approximately $5 \mathrm{~h}$. The gel was autoradiographed overnight at $-70^{\circ} \mathrm{C}$ with intensifying screens.

Direct sequencing. Genomic DNA from individuals with variant single-strand conformers was used as a template in the amplification reaction as described above (total volume $50 \mu \mathrm{l} \mathrm{con-}$ taining $25 \mathrm{pmol}$ of each primer and 1.25 units of Dynazyme DNA polymerase). Amplified segments were purified by electrophoresis on a $1 \%$ low-melting-point agarose gel and directly sequenced using Sequenase (US Biochemicals, Cleveland, Ohio, USA), as described previously [35].

Determination of the frequencies of the variants in exons 2, 7, 10, 11 and intron 14. Exons 2, 7, 10 and 11 were amplified with non-radioactive PCR in a volume of $20 \mu \mathrm{l}$ with the primers reported previously [22] and the reaction conditions described above. To determine the frequencies of variants in these exons and intron 14, the PCR products were digested with an appropriate enzyme and separated through a $3 \%$ agarose gel (NuSieve; FMC BioProducts, Rockland, M.E., USA). The Gln 71 His variant $(C A G \rightarrow C A C)$ of exon 2 creates an additional cutting site for SduI enzyme in this PCR product (279 bp). Therefore, the His-encoding allele gives fragments of 133,99 and 47 bp and the Gln-encoding allele gives fragments of 232 and $47 \mathrm{bp}$. The silent substitution TTC342TTT of exon 7 abolishes one of the two cutting sites for BstNI restriction enzyme in this PCR product (189 bp). As a result, the TTC allele is represented as 115, 43 and $31 \mathrm{bp}$ fragments and the TTT allele by 158 and 31 bp fragments. The new Met416Val polymorphism of exon 10 was determined by restriction enzyme digestion with Hsp92II, because the nucleotide change (AT$\mathrm{G} \rightarrow \mathrm{GTG}$ ) abolishes one of the three cleaving sites for this enzyme in the amplified 172 bp segment. The Met-encoding allele migrates as 106, 37, 25 and 4 bp fragments, whereas the Val-encoding allele migrates as 143,25 and 4 bp fragments. The Gly464Ser variant (GGC $\rightarrow$ AGC) of exon 11 disrupts the unique restriction site for HaeIII enzyme. Therefore, the Glyencoding allele migrates as 105 and $54 \mathrm{bp}$ fragments and the Ser-encoding allele as an intact 159 bp fragment. Furthermore, the region flanking the XbaI polymorphism (CCTAGA $\rightarrow$ TCTAGA) in intron 14 was amplified with a forward primer 5'CTCС TTCCTCTACAGTTTCTG (in exon 14) and a reverse primer 5'GTGAGTCTCCTCTTTGGCCA (in intron 14). The PCR product was digested with $\mathrm{XbaI}$ restriction enzyme, which cleaves the $A_{2}$ allele into segments of 500 and 100 bp long, whereas $A_{1}$ (common) allele remains intact.

Statistical analysis. All calculations were performed using the SPSS/Win programs (SPSS Inc., Chicago, Ill., USA). The frequencies between the study groups were compared with the chi-square test and continuous variables with Student's twotailed $t$-test, when appropriate. For comparison of two groups, the confounding factors were adjusted with the analysis of covariance. Because of the skewed distribution, insulin was logarithmically transformed before statistical analyses to obtain a normal distribution. All data are presented as mean \pm SEM.

\section{Results}

Initial screening for the variants of the GYS1 gene. All 16 exons and exon-intron junctions were first screened in 40 patients with NIDDM by SSCP analysis. 
Table 2. The allele frequencies (number of alleles in parenthesis) of variants $( \pm$ SEM) in the glycogen synthase gene found in NIDDM and control subjects in the initial and additional screening

\begin{tabular}{|c|c|c|c|}
\hline & \multirow{2}{*}{$\begin{array}{l}\text { Initial screening } \\
\text { NIDDM } \\
(n=40)\end{array}$} & \multicolumn{2}{|c|}{ Additional screening } \\
\hline & & $\begin{array}{l}\text { NIDDM } \\
(n=105)\end{array}$ & $\begin{array}{l}\text { Normoglycaemic Group } 1 \\
(n=82)\end{array}$ \\
\hline Gln71His & $0.01 \pm 0.02(1)$ & $0.005 \pm 0.009(1)$ & - \\
\hline \multicolumn{4}{|l|}{ Exon 7} \\
\hline TTC342TTT & $0.30 \pm 0.10(24)$ & $0.29 \pm 0.06(60)$ & $0.29 \pm 0.07(48)$ \\
\hline \multicolumn{4}{|l|}{ Exon 11} \\
\hline Gly464Ser & $0.04 \pm 0.04$ & $0.01 \pm 0.01(3)$ & - \\
\hline \multicolumn{4}{|l|}{ intron 14} \\
\hline CCTAGA $\rightarrow$ TCTAGA & $0.06 \pm 0.05(5)$ & $0.10 \pm 0.04(21)$ & $0.11 \pm 0.05(18)$ \\
\hline
\end{tabular}

Statistical comparisons between the NIDDM group $(n=105)$ and the normoglycaemic Group $1(n=82)$ were all non-significant

Abnormally migrating bands were observed in exons $2,7,10$ and 11 (Table 2). We found the silent polymorphism TTC342TTT of exon 7 and the Gly464Ser variant of exon 11 as reported previously [22, 23]. Two new variants were found, the Gln 71 His substitution in exon 2 and the Met416Val polymorphism in exon 10.The Gln71His variant was found in only one $(2.5 \%)$ and the Gly464Ser variant in $3(7.5 \%)$ patients with NIDDM $(n=40)$. All these subjects were heterozygous for these variants. The Met416Val substitution was more frequent; there were 6 heterozygous carriers (15\%) of this substitution among 40 patients with NIDDM. In addition, the allelic frequency of the $\mathrm{A}_{2}$ allele of the Xbal-polymorphism was 0.06 in 40 patients with NIDDM.

Additional screening for the GYS1 gene variants. We screened the observed variants of the GYS1 gene in additional samples from 65 patients with NIDDM and from 82 normoglycaemic men (Group 1). The TTC342TTT silent polymorphism of exon 7 was the most common variant with an allele frequency of 0.29 in both the NIDDM $(n=105)$ and normoglycaemic group $(n=82)$ (Table 2). The Met416Val polymorphism also occurred at similar allele frequencies, 0.08 and 0.09 in the NIDDM and normoglycaemic groups, respectively $(p=N S)$. The allelic frequency of the $\mathrm{A}_{2}$ allele of the XbaI-polymorphism was 0.10 in NIDDM patients and 0.11 in normoglycaemic subjects $(p=\mathrm{NS})$. The additional screening did not reveal any other carriers of the Gln71His and Gly464Ser substitutions, and neither of these variants was observed in the normoglycaemic group. Among patients with NIDDM $(n=105)$ the allele frequencies of the Gln 71 His and Gly464Ser variants were 0.005 and 0.01 , respectively.

Metabolic studies in normoglycaemic subjects (Groups 1 and 2). The effect of the Met416Val polymorphism on insulin sensitivity was determined in two groups of normoglycaemic subjects. Insulin sensitivity of subjects in Group $1(n=82)$ was estimated with the euglycaemic clamp and in Group 2 $(n=295)$ with the insulin sensitivity index $\left(\mathrm{S}_{\mathrm{i}}\right)$ based on an intravenous glucose tolerance test. In Group 1 fasting glucose and insulin levels were similar in subjects with and without the Val-encoding allele (Table 3). On the other hand, a 2-h insulin level was significantly higher after logarithmic transformation in subjects with the Val-encoding allele than in subjects with Met-encoding allele $(p=0.02)$. In Group 1 the rates of whole body glucose uptake were slightly lower in subjects with the Val-encoding allele, but the difference was not statistically significant. In Group 2 the subjects with the Val-encoding allele had a significantly higher level of fasting glucose after adjustment for age ( $p=0.03$ ), but fasting insulin was similar in subjects with and without the Val-encoding allele. Both 1- and 2-h insulin levels tended to be higher in subjects with the Val-encoding allele, although the differences did not reach statistical significance. Furthermore, the insulin sensitivity index $\left(\mathrm{S}_{\mathrm{i}}\right)$ and glucose effectiveness $\left(S_{\mathrm{G}}\right)$ did not differ between the subjects with and without the Met416Val polymorphism.

Association of insulin resistance with the Gly464Ser variant. Five pedigrees (three with NIDDM and two with familial combined hyperlipidaemia) with the Gly464Ser variant of the GYS1 gene were found. When the data of the probands and their first-degree relatives (spouses excluded) from these families were pooled (13 subjects with the Gly464Gly genotype and 17 subjects with the Gly464Ser genotype), both fasting plasma insulin as well as the rates of whole body glucose uptake during the euglycaemic clamp study were unaffected by this variant (Table 4). In families with NIDDM the fasting levels of insulin were unaffected by the Gly464Ser variant $(85.7 \pm 11.0 \mathrm{pmol} / \mathrm{l}$ in subjects with the Gly464Gly 
Table 3. Fasting plasma glucose, insulin values and the results of metabolic studies according to the Met416Val polymorphism of exon 10 of the glycogen synthase gene in 82 (Group 1) and 295 (Group 2) normoglycaemic subjects

\begin{tabular}{|c|c|c|c|c|}
\hline & \multicolumn{2}{|c|}{ Group $1(n=82)$} & \multicolumn{2}{|c|}{ Group $2(n=295)$} \\
\hline & $\begin{array}{l}\text { Met416Met } \\
(n=68)\end{array}$ & $\begin{array}{l}\text { Met416Val } \\
(n=14)\end{array}$ & $\begin{array}{l}\text { Met416Met } \\
(n=257)\end{array}$ & $\begin{array}{l}\text { Met416Val } \\
(n=38)\end{array}$ \\
\hline Fasting insulin (pmol/l) & $54.0 \pm 4.4$ & $65.3 \pm 8.9$ & $58.2 \pm 1.8$ & $60.4 \pm 5.6$ \\
\hline 1-h insulin (pmol/l) & $408.6 \pm 47.6$ & $530.0 \pm 92.2$ & $396.6 \pm 16.3$ & $439.8 \pm 53.9$ \\
\hline 2-h insulin $(\mathrm{pmol} / \mathrm{l})$ & $190.6 \pm 27.8$ & $299.4 \pm 65.8^{b}$ & $263.0 \pm 10.8$ & $310.4 \pm 43.3$ \\
\hline $\begin{array}{l}\text { Whole body glucose uptake } \\
\left(\mu \mathrm{mol} \cdot \mathrm{kg}^{-1} \cdot \mathrm{min}^{-1}\right)\end{array}$ & $58.8 \pm 1.8$ & $54.3 \pm 3.1$ & - & - \\
\hline $\mathrm{S}_{\mathrm{i}}\left(\cdot 10^{-4} \mu \mathrm{U}^{-1} \cdot \mathrm{ml}^{-1}\right)$ & - & - & $4.3 \pm 0.2$ & $4.1 \pm 0.5$ \\
\hline$S_{\mathrm{G}}\left(\min ^{-1}\right)$ & - & - & $0.021 \pm 0.001$ & $0.021 \pm 0.001$ \\
\hline
\end{tabular}

Data are means \pm SEM. ${ }^{\mathrm{a}} p=0.03$ after adjustment for age; ${ }^{\mathrm{b}} p=0.02$ after logarithmic transformation

Table 4. The effect of Gly464Ser variant of the glycogen synthase gene on fasting plasma insulin and whole body glucose uptake during the euglycaemic clamp in probands and their first-degree relatives from 3 families with non-insulin-dependent diabetes mellitus and 2 families with familial combined hyperlipidaemia

\begin{tabular}{llll}
\hline & $\begin{array}{l}\text { Gly464Gly } \\
(n=13)\end{array}$ & $\begin{array}{l}\text { Gly464Ser } \\
(n=17)\end{array}$ & $P$ value \\
\hline Gender (male/female) & $2 / 11$ & $10 / 7$ & 0.011 \\
Age (years) & $55.4 \pm 3.4$ & $54.5 \pm 4.2$ & $\mathrm{NS}$ \\
Body mass index $\left(\mathrm{kg} / \mathrm{m}^{2}\right)$ & $28.4 \pm 1.7$ & $25.0 \pm 0.9$ & 0.081 \\
$\begin{array}{l}\text { Fasting insulin }(\mathrm{pmol} / \mathrm{l}) \\
\text { Whole body glucose uptake }\end{array}$ & $70.5 \pm 7.3$ & $76.0 \pm 5.8$ & $\mathrm{NS}^{\mathrm{a}}$ \\
$\left(\mu \mathrm{mol} \cdot \mathrm{kg}^{-1} \cdot \mathrm{min}^{-1}\right)$ & $57.4 \pm 9.8$ & $59.4 \pm 6.1$ & $\mathrm{NS}$ \\
\hline
\end{tabular}

${ }^{a}$ Adjusted for gender. ${ }^{b}$ Available for 3 subjects ( 1 man, 2 women) with the Gly464Gly genotype and 6 subjects ( 4 men, 2 women) with the Gly464Ser genotype from normoglycaemic subjects of families with familial combined hyperlipidaemia. Data are mean $\pm S E M$

genotype vs $76.4 \pm 6.2 \mathrm{pmol} / 1$ in subjects with the Gly464Ser genotype, $p=0.449$ ). Although in families with familial combined hyperlipidaemia subjects with the Gly464Ser genotype tended to have higher levels of fasting insulin than subjects with the Gly464Gly genotype (73.8 \pm 9.9 vs $55.4 \pm 5.5 \mathrm{pmol} / \mathrm{l})$, this difference was not statistically significant $(p=0.141)$.

\section{Discussion}

The major part of insulin resistance in patients with NIDDM is due to impaired storage of glucose as glycogen $[3,5]$. The possibility that this defect is inherited is supported by positive associations between the markers of the GYS1 gene and NIDDM in the Finnish [15], French [16], Japanese [17] and Pima Indian [18] populations as well as studies showing impaired activity of GS in normoglycaemic first-degree relatives of NIDDM patients [7, 14]. These data suggest that defects in the GYS1 gene might contribute to insulin resistance in patients with NIDDM. In the present study we found two previously unreported substitutions of this gene, Gln71His and Met416Val. The Met416Val was not associated with insulin resistance in normoglycaemic subjects and the Gln71His was so uncommon that we were unable to investigate its possible effect on insulin sensitivity. In addition, the previously reported Gly464Ser variant of the GYS1 gene was not associated with insulin resistance in the families studied.

The variants in the coding region of the GYS1 gene were quite uncommon in patients with NIDDM. The Gln71His and Gly464Ser substitutions were specific for patients with NIDDM, but the allele frequencies of these variants appeared to be low $(0.005$ and 0.01 , respectively). In a previous study from western Finland the allele frequency of the Gly464Ser variant was even lower (0.005) in patients with NIDDM [22]. Therefore, these variants cannot contribute substantially to the risk of NIDDM in the Finnish population. The silent polymorphism TTC342TTT of exon 7 was found at a similar frequency in NIDDM and control subjects as previously described in other Caucasian populations $[22,23]$. Despite the application of similar techniques, this common polymorphism was not found in Pima Indians [18]. The XbaI-polymorphism of intron 14 was previously associated with NIDDM in the Finnish $\left(\mathrm{A}_{2}\right.$ allele) [15] and French populations $\left(A_{1}\right.$ allele) [16], but we and Japanese investigators [17] could not verify that finding.

The new polymorphism, Met416Val, was found in exon 10.The allele frequencies were similar in both NIDDM and control groups (0.08 vs 0.09$)$ implying that this polymorphism does not have a major effect on the risk of NIDDM. The influence of this polymorphism on insulin sensitivity was further evaluated in two groups of normoglycaemic subjects. The Met416Val polymorphism was not associated with insulin 
resistance in either group (Table 3). However, the 2-h insulin level in group 1 was significantly higher in subjects with the Val-encoding allele $(p=0.02)$, and in group 2 subjects with the Val-encoding allele also tended to have higher 1 - and $2-\mathrm{h}$ insulin levels. These results imply that in our study subjects the Met416Val polymorphism is unlikely to have a major effect on insulin sensitivity.

We screened the first-degree relatives of five probands (three with NIDDM and two with familial combined hyperlipidaemia) with respect to the Gly464Ser variant and correlated the results with insulin levels and insulin sensitivity determined by the euglycaemic clamp. A previous study from Finland [22] has indicated that the Gly464Ser variant is associated with severe insulin resistance. In our study, however, the subjects with the Gly464Ser variant were not more insulin resistant than the subjects without this mutation (Table 4 ). Therefore, our results do not provide any support for the hypothesis that the Gly464Ser variant of the GYS1 gene is a major cause of insulin resistance.

Sequential phosphorylation of the GS protein by kinases leads to gradual inactivation of the enzyme in the absence of glucose 6-phosphate, whereas dephosphorylation of GS by glycogen synthase phosphatase enhances the activity of the GS enzyme. Since the serine phosphorylation sites at the N- or Cterminal ends of the protein are thought to be most important for regulation [36], the Gly464Ser substitution of exon 11 is unlikely to change the activity of a functional GS enzyme by this mechanism. The amino acid sequence at the phosphorylation sites in the Cterminus (124 C-terminal amino acids) of the GS protein is highly conserved between human and rabbit. Because it is likely to interact with glycogen [36], the C-terminal end of the protein might be of importance for catalytic activity of the enzyme. Since no accurate information is available on tertiary structure of the GS protein, the influence of the Gln71His, Met416Val and Gly464Ser substitutions on activity or function of the GS enzyme remains to be determined in expression studies.

Based on the present and previous studies [18, 2123] it seems unlikely that variants of the GYS1 gene are major contributors to insulin resistance or to NIDDM, assuming that all relevant variants have been detected by the SSCP analysis [37]. Our SSCP conditions have previously been validated against known variants of the lipoprotein lipase gene [38, 39]. Furthermore, the SSCP analysis we used has been successfully applied in the screening of variants in the red and green opsin genes [40, 41], insulin receptor substrate-1 [30], and hexokinase II [42]. Therefore, it is unlikely that we have missed a significant proportion of variants of the GYS1 gene. However, gene defects contributing to low activity of GS can also be located at other genes which are in linkage disequilibrium with the GYS1 locus. These defects could reduce the activity of GS, for example, by changing allosteric or covalent regulation of GS or by affecting the insulin signalling pathway which leads to the activation of GS.

In conclusion, we found two previously unreported variants, Gln71His and Met416Val, in the coding region of the glycogen synthase gene in patients with NIDDM from eastern Finland. The Met416Val and Gly464Ser substitutions did not significantly affect insulin sensitivity in normoglycaemic subjects, and the Gln71His variant appeared to be very uncommon in patients with NIDDM. Therefore, the variants of the glycogen synthase gene are unlikely to play a major role in the predisposition to insulin resistance and NIDDM.

Acknowledgements. This study was supported by a grant from the Medical Research Council of the Academy of Finland.

\section{References}

1. Leloir LF, Olavaria JM, Goldenburg SH, Carminatti H (1959) Biosynthesis of glycogen from uridine diphosphate glucose. Arch Biochem Biophys 81: 508-520

2. Mandarino LJ, Wright KS, Verity LS et al. (1987) Effect of insulin infusion on human skeletal muscle pyruvate dehydrogenase, phosphofructokinase, and glycogen synthase. Evidence for their role in oxidative and nonoxidative glucose metabolism. J Clin Invest 80: 655-663

3. Shulman GI, Rothman DL, Jue T, Stein P, DeFronzo RA, Shulman RG (1990) Quantitation of muscle glycogen synthesis in normal subjects and subjects with non-insulin-dependent diabetes by ${ }^{13} \mathrm{C}$ nuclear magnetic resonance spectroscopy. N Engl J Med 322: 223-228

4. Thorburn AW, Gumbiner B, Bulacan F, Brechtel G, Henry RR (1991) Multiple defects in muscle glycogen synthase activity contribute to reduced glycogen synthesis in non-insulin dependent diabetes mellitus. J Clin Invest 87: 489-495

5. Vestergaard H, Lund S, Larsen FS, Bjerrum OJ, Pedersen O (1993) Glycogen synthase and phosphofructokinase protein and mRNA levels in skeletal muscle from insulin-resistant patients with non-insulin-dependent diabetes mellitus. $\mathrm{J}$ Clin Invest 91: 2342-2350

6. Bogardus C, Lillioja S, Stone K, Mott D (1984) Correlation between muscle glycogen synthase activity and in vivo insulin action in man. $J$ Clin Invest $73: 1185-1190$

7. Schalin-Jäntti C, Härkönen M, Groop LC (1992) Impaired activation of glycogen synthase in people at increased risk for developing NIDDM. Diabetes 41: 598-604

8. Thorburn AW, Gumbiner B, Bulacan F, Wallace P, Henry RR (1990) Intracellular glucose oxidation and glycogen synthase activity are reduced in non-insulin-dependent (type II) diabetes independent of impaired glucose uptake. J Clin Invest 85: 522-529

9. Johnson AB, Argyraki M, Thow JC, Broughton D, Jonens IR, Taylor R (1990) Effects of intensive dietary treatment on insulin-stimulated skeletal muscle glycogen synthase activation and insulin secretion in newly presenting type 2 diabetic patients. Diabet Med 7: 420-428

10. Freymond D, Bogardus C, Okubo M, Stone K, Mott D (1988) Impaired insulin-stimulated muscle glycogen synthase activation in vivo in man is related to low fasting 
glycogen synthase phosphatase activity. J Clin Invest 82: 1503-1509

11. Damsbo P, Vaag A, Hother-Nielsen O, Beck-Nielsen $H$ (1991) Reduced glycogen synthase activity in skeletal muscle from obese patients with and without type 2 (non-insulin-dependent) diabetes mellitus. Diabetologia 34: 239-245

12. Kelley DE, Mandarino LJ (1990) Hyperglycemia normalizes insulin-stimulated skeletal muscle glucose oxidation and storage in non-insulin-dependent diabetes mellitus. J Clin Invest 86: 1999-2007

13. Löfman M, Yki-Järvinen H, Parkkonen M et al. (1995) Increased concentrations of glycogen synthase protein in skeletal muscle of patients with NIDDM. Am J Physiol 269: E27-E32

14. Vaag A, Henriksen JE, Beck-Nielsen H (1992) Decreased insulin activation of glycogen synthase in skeletal muscles in young nonobese Caucasian first-degree relatives of patients with non-insulin-dependent diabetes mellitus. J Clin Invest 89: 782-788

15. Groop LC, Kankuri M, Schalin-Jäntti C et al. (1993) Association between polymorphism of the glycogen synthase gene and non-insulin-dependent diabetes mellitus. $\mathrm{N}$ Engl J Med 328: 10-14

16. Zouali H, Velho G, Froguel P (1993) Polymorphism of the glycogen synthase gene and non-insulin-dependent diabetes mellitus. N Engl J Med 328: 1568-1569

17. Kuroyama H, Sanke T, Ohagi S, Furuta M, Furuta H, Nanjo K (1994) Simple tandem repeat DNA polymorphism in the human glycogen synthase gene is associated with NIDDM in Japanese subjects. Diabetologia 37: 536-539

18. Majer M, Mott DM, Mochizuki H et al. (1996) Association of the glycogen synthase locus on 19q13 with NIDDM in Pima Indians. Diabetologia 39: 314-321

19. Wells AM, Sutcliffe IC, Johnson AB, Taylor R (1993) Abnormal activation of glycogen synthesis in fibroblasts from NIDDM subjects. Diabetes 42: 583-589

20. Henry RR, Ciaraldi TP, Abrams-Carter L, Mudaliar S, Park KS, Nikoulina SE (1996) Glycogen synthase activity is reduced in cultured skeletal muscle cells of non-insulindependent diabetes mellitus subjects. J Clin Invest 98: 1231-1236

21. Vestergaard H, Björbaek C, Andersen PH, Bak JF, Pedersen O (1991) Impaired expression of glycogen synthase mRNA in skeletal muscle of NIDDM patients. Diabetes 40: $1740-1745$

22. Orho $M$, Nikula-Ijäs $P$, Schalin-Jäntti $C$, Permutt MA, Groop LC (1995) Isolation and characterization of the human muscle glycogen synthase gene. Diabetes 44: 10991105

23. Bjørbæk C, Echwald SM, Hubricht P et al. (1994) Genetic variants in promoters and coding regions of the muscle glycogen synthase and the insulin-responsive GLUT4 genes in NIDDM. Diabetes 43: 976-983

24. De la Chapelle A (1993) Disease gene mapping in isolated human populations: the example of Finland. J Med Genet 30: $857-865$

25. Sarlund H, Pyörälä K, Penttilä I, Laakso M (1992) Early abnormalities in coronary heart disease risk factors in relatives of subjects with non-insulin dependent diabetes. Arterioscler Thromb 12: 657-663

26. Haffner SM, Karhapää P, Mykkänen L, Laakso M (1994) Insulin resistance, body fat distribution, and sex hormones in men. Diabetes 43: 212-219

27. World Health Organization (1985) Diabetes mellitus: Report of a WHO study group. Geneva. World Health Organization (Tech Rep Ser, no. 727)

28. Laakso M, Rönnemaa T, Pyörälä K, Kallio V, Puukka P, Penttilä I (1988) Atherosclerotic vascular disease and its risk factors in non-insulin dependent diabetic subjects in Finland. Diabetes Care 11: 449-463

29. DeFronzo RA, Tobin JD, Andres R (1979) Glucose clamp technique: a method for guantifying insulin secretion and insulin resistance. Am J Physiol 237:E214-E223

30. Laakso M, Malkki M, Kekäläinen P, Kuusisto J, Deeb SS (1994) Insulin receptor substrate-1 variants in non-insulindependent diabetes. J Clin Invest 94: 1141-1146

31. Bergman RN, Finegood DT, Ader M (1985) Assessment of insulin sensitivity in vivo. Endocrinol Rev 5: 45-86

32. Steil GM, Volund A, Kahn SE, Bergman RN (1993) Reduced sample number for calculation of insulin sensitivity and glucose effectiveness from the minimal model. Suitability for use in population studies. Diabetes 42: 250-256

33. Bergman RN, Ider YZ, Bowden CR, Cobelli C (1979) Quantitative estimation of insulin sensitivity. Am J Physiol 236:E667-E677

34. Orita $M$, Iwahana $H$, Kanazawa $H$, Hayashi $K$, Sekiya $T$ (1989) Detection of polymorphisms of human DNA by gel electrophoresis as single-strand conformation polymorphisms. Proc Natl Acad Sci U S A 86: 2766-2770

35. Kretz KA, Carson GS, O'Brien JS (1989) Direct sequencing from low-melt agarose with Sequenase. Nucleic Acids Res 17: 5864

36. Browner MF, Nakano K, Bang AG, Fletterich RJ (1989) Human muscle glycogen synthase cDNA sequence: a negatively charged protein with an asymmetric charge distribution. Proc Natl Acad Sci U S A 86: 1443-1447

37. Fan E, Levin DB, Glickman BW, Logan DM (1993) Limitations in the use of SSCP analysis. Mutation Research 288: 85-92

38. Reina M, Brunzell JD, Deeb SS (1992) Molecular basis of familial chylomicronemia: mutations in the lipoprotein lipase and apolipoprotein C-II genes. J Lipid Res 33: 18231832

39. Nevin DN, Brunzell JD, Deeb SS (1994) The LPL gene in individuals with familial combined hyperlipidaemia and decreased LPL activity. Arterioscler Thromb 14: 869-873

40. Winderickx J, Lindsey DT, Sanochi E, Teller DY, Motulsky AG, Deeb SS (1992) Polymorphism in red photopigment underlies variation in colour matching. Nature 356: 431433

41. Winderickx J, Battisti L, Motulsky AG, Deeb SS (1992) Selective expression of human $\mathrm{X}$ chromosome-linked green opsin genes. Proc Natl Acad Sci U S A 89: 9710-9714

42. Laakso M, Malkki M, Deeb SS (1995) Amino acid substitutions in hexokinase II among patients with NIDDM. Diabetes 44 : $330-334$ 